\title{
POTENTIATION OF PRESSOR EFFECTS OF NOR-EPINEPHRINE AND EPINEPHRINE IN MAN BY DESOXYCORTICOSTERONE ACETATE ${ }^{1}$
}

\author{
BY W. RAAB, R. J. HUMPHREYS, AND E. LEPESCHKIN 2 \\ (From the Division of Experimental Medicine of the University of Vermont, College of Medicine, \\ Burlington, and the Vermont State Hospital, Waterbury, Vermont)
}

(Submitted for publication May 1, 1950; accepted, July 24, 1950)

In connection with the problem of the possible role played by the sympathomimetic neurohormones (nor-epinephrine and epinephrine) in the pathogenesis of essential hypertension, interest has been focused lately on substances which are capable of abnormally intensifying the vasoconstrictor power of epinephrine in the mesentery of the rat and the perfused rabbit's ear, such as the chemically undefined agent "VEM" which originates in the kidney (1) and protein fractions, extracted from the kidneys and other tissues, as well as hypertensin and tyrosin (2).

A participation of adrenal cortical steroids in such "sensitizing" mechanisms is suggested by the restoration of the impaired VEM formation in the kidneys of adrenalectomized animals $(3,4)$ and by the enhancement of the vasoconstrictor effect of epinephrine on the perfused rabbit's ear, by addition of adreno-cortical extracts (5).

In the intact dog and cat, subthreshold doses of epinephrine showed pressor activity after pretreatment with adrenal cortical hormones (6), and in normotensive human subjects the pressor effect of subcutaneously injected epinephrine proved markedly intensified after several days of pretreatment with daily doses of 10 to $50 \mathrm{mg}$. of desoxycorticosterone acetate $(7,8)$. On the other hand, the blood pressure effect of epinephrine has been reported as being weakened in patients with hypoadrenocorticism (9-11).

The phenomenon of enhancement of the pressor action of epinephrine by desoxycorticosterone does not develop immediately after administration of the latter but seems to require a certain interval of latency, as indicated by its absence in the case of simultaneous intravenous injection of desoxycorticosterone glucoside and epinephrine $(12,13)$.

1 This study was aided in part by a grant from the National Heart Institute.

2 During the tenure of a research fellowship of The American Heart Association.
In view of the fact that the earlier experiments in desoxycorticosterone acetate-pretreated human subjects $(7,8)$ had been carried out by use of the subcutaneous route of epinephrine administration, and considering the possibility that the finding of an increased pressor effect of epinephrine after desoxycorticosterone acetate might have been misleading due to an altered speed of subcutaneous absorption of the injected epinephrine, the following experiments with intravenous infusions of epinephrine were planned in order to obtain more conclusive results by avoiding that source of error.

Furthermore, we decided to carry out analogous experiments also with equal doses of nor-epinephrine, because this substance is assuming steadily increasing significance as an adrenal medullary hormone (14-16), as the physiological chemical neurotransmitter of the sympathetic nervous system (17) and as a pressor agent whose hemodynamic effects are much more similar to the hemodynamic peculiarities of patients with essential hypertension than those produced by epinephrine. Nor-epinephrine elevates both the systolic and diastolic pressure through general vasoconstriction and does not produce cardiac acceleration in contrast to the prevailingly heartstimulating and accelerating effect of epinephrine, which functions largely as a vasodilator and produces its pressor action mainly by augmenting the cardiac output, leaving the diastolic pressure more or less unchanged or even lowering it (14, 18-20).

\section{METHODS}

Fifteen physically normal male patients of the Vermont State Hospital, ${ }^{3}$ aged 16 to 56 (average 37) years

${ }^{8} \mathrm{We}$ are indebted to Dr. R. Chittick, Superintendent of the Vermont State Hospital, for permission to carry out our investigative work in that institution, and to the hospital staff for friendly cooperation. 
(three of them borderline hypertensives), were subjected to the following tests before, and again at the conclusion of periods of seven to 22 (average 17) days on which they received daily injections of $10 \mathrm{mg}$. of desoxycorticosterone acetate (Percorten) 4 intramuscularly: (1) Resting blood pressure level (auscultatory method; same observer); (2) Roentgenographic diameter of the heart; (3) Serum sodium and potassium (flame photometer); (4) Pressor effects of intravenous infusions of epinephrine and 1-norepinephrine (1-arterenol) ${ }^{3}$ were tested in the following manner: A 19 gauge needle was inserted in the left cubital vein of the recumbent patient. The needle was connected with two three-way stopcocks, attached to each other and connected with three suspended $250 \mathrm{cc}$.

- Percorten (desoxycorticosterone acetate) was supplied in generous quantities by Ciba Laboratories, Inc., through the courtesy of Dr. Ernst Oppenheimer.

5 Dr. M. L. Tainter of the Sterling-Winthrop Research Institute kindly put to our disposal an ample supply of 1-arterenol (1-nor-epinephrine). infusion bottles. One of these bottles contained plain saline solution, the two others contained freshly prepared solutions of epinephrine and nor-epinephrine respectively. These solutions were made by adding $1 \mathrm{cc}$. of 1:1,000 epinephrine and 1-nor-epinephrine respectively to each of two $250 \mathrm{cc}$. saline bottles. Each bottle was equipped with a "Venopak" venoclysis unit, the outflow from which was calibrated by counting the drops necessary to fill a $10 \mathrm{cc}$. space in a test tube. The figure thus obtained was multiplied with the weight of the patient in kilograms and divided by 400 to determine the number of drops required for the dose of 0.1 microgram of epinephrine or nor-epinephrine per kilogram per minute. (Example: Number of drops per $10 \mathrm{cc}$. : 175.; weight of patient : $80 \mathrm{~kg}$.; number of infused drops per minute for dose above mentioned : $\frac{175 \times 80}{400}=35$.) First, saline was slowly infused at a rate of about 40 drops per minute until a stable minimal blood pressure was reached and then, unbeknown to the patient, the inflow into the vein was switched to the epinephrine bottle by changing clamps

\section{NOR-EPINEPHRINE (ARTERENOL) INFUSIONS BEFORE DCA}

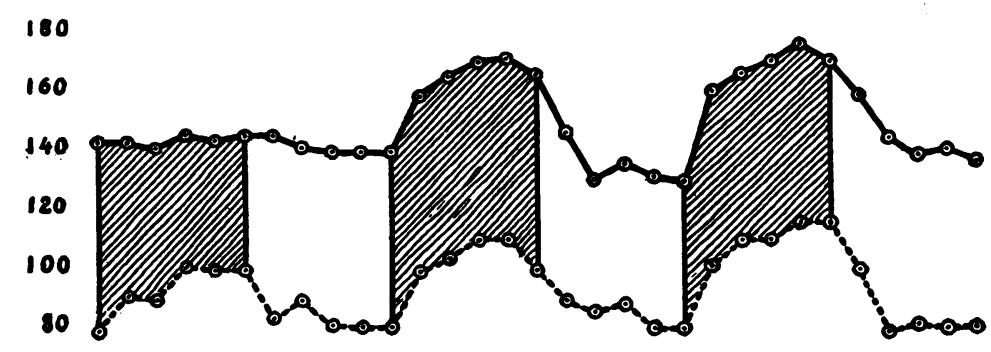

\section{AFTER DCA (18 DAYS, $10 \mathrm{mg}$ each)}

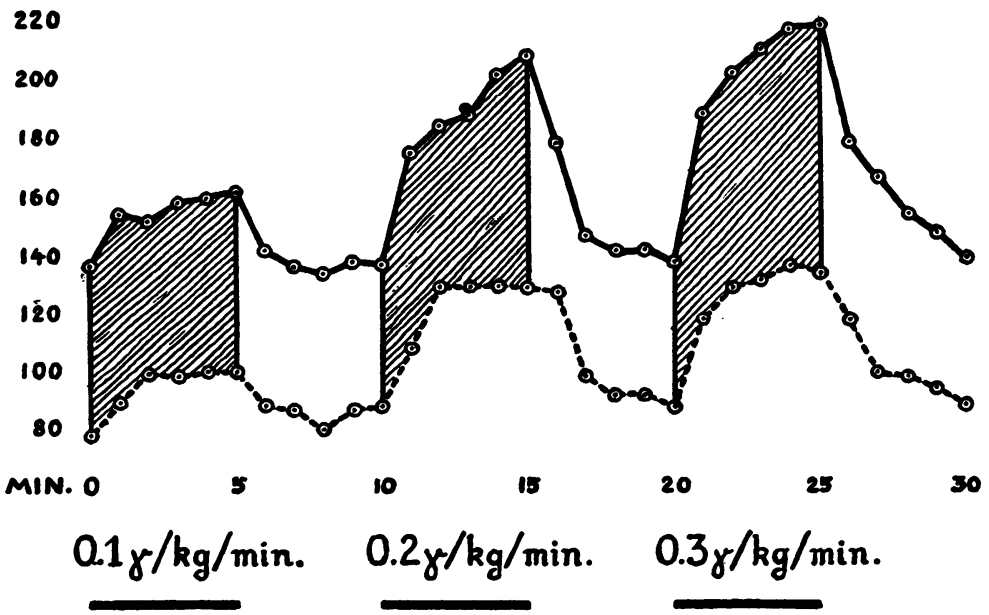

Fig. 1. Detailed Blood Pressure Curves of Case No. 4 (Nor-Epinephrine Before and After Desoxycorticosterone Acetate)

In most of the other cases the intervals between individual infusion periods were longer because of slower reestablishment of the base level. 


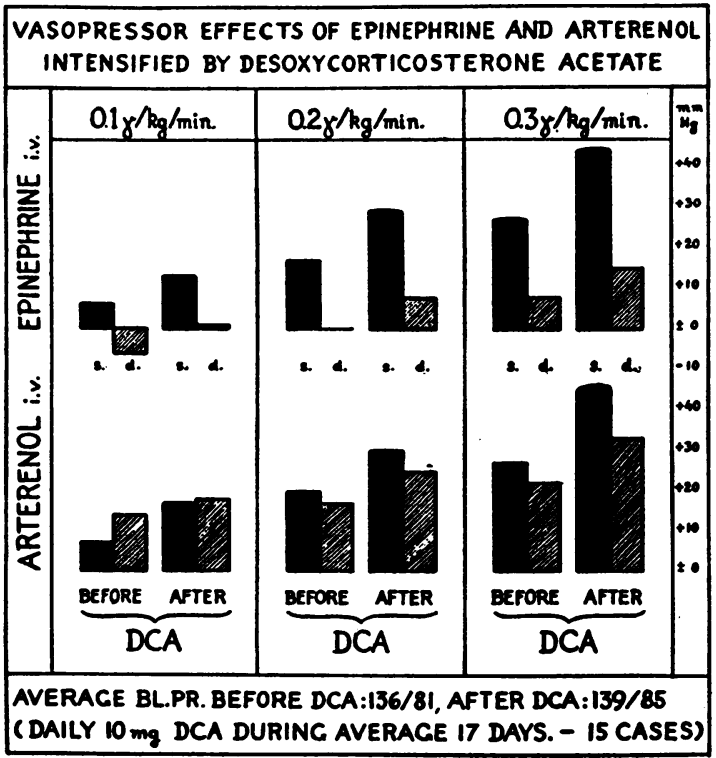

FIG. 2.

on the tubings. With the screw of a pinchcock attached to the Venopak tubing the drop count was regulated and maintained constant during the infusion period by synchronizing each falling drop with the clack of an electric metronome. The metronome had been set previously at the speed required for the number of drops supplying 0.1 microgram of epinephrine per kilogram per minute (e.g., 35, [see above]). Blood pressure readings and electrocardiograms were recorded before infusion and at the end of each minute during the five minute infusion period after which the inflow was switched back to saline. Blood pressure and electrocardiogram readings were continued also during the following five minutes. As soon as the blood pressure had again become stabilized at or near the pre-infusion level, the same procedure was repeated in most of the cases with 0.2 microgram per kilogram per minute (double number of drops) and finally with 0.3 microgram per kilogram per minute. After this, the inflow was switched from epinephrine to nor-epinephrine and analogous tests with the same doses were carried out (Figures 1 and 2).

The entire test procedure was repeated on the day following the last injection of desoxycorticosterone acetate (Figures 1 and 2). Shortly before each test series each of these mental patients was given an oral dose of sodium pentobarbital (60 to $100 \mathrm{mg}$.) for sedation. Although a slight central vasodepressant effect of this medication had to be reckoned with, it was perferred as a minor and standardized source of error to the unpredictable pressor effects of uninhibited and varying emotional states.

All 15 patients received the regular hospital diet but seven of them were given in addition a daily dose of 10 grams of sodium chloride in enteri-coated tablets during the entire period of medication with desoxycorticosterone acetate. These seven cases will be designated in the following as group $B$ in contrast to the eight patients (group A) who received no extra salt. The average ages of groups A and B were about the same (36 and 37 years, respectively). The average blood pressure level of group A was 142/84, that of group B was $130 / 77$. Both groups received an average of 17 injections of desoxycorticosterone acetate (10 mg. each).

\section{RESULTS}

By comparing the findings before and after the period of desoxycorticosterone administration the following results were obtained:

(1) Resting blood pressure level. The average systolic and diastolic blood pressure levels remained practically unchanged in group A (eight patients with a normal salt intake), while there was a slight average increase in group B (seven patients receiving a daily extra dose of 10 grams of salt) (Table I).

(2) Heart size. The diameter of the heart was increased in six out of seven cases of group A ( +5 to $+11 \mathrm{~mm}$., average $+6 \mathrm{~mm}$.) and in five cases of group B ( +2 to $+17 \mathrm{~mm}$., average $+8 \mathrm{~mm}$.) (Table I). The roentgenographic findings in three cases had to be discarded because of differences in the position of the diaphragms.

(3) Serum electrolytes. The average sodium level remained practically unchanged in groups $\mathrm{A}$ and B (140 meq before, $141 \mathrm{meq}$ after desoxycorticosterone acetate in both groups). The average potassium was diminished in all cases (average from $4.6 \mathrm{meq}$ to $3.6 \mathrm{meq}$ in group A; from 4.4 meq to 3.7 meq in group B).

(4) Pressor effect of epinephrine before and after desoxycorticosterone acetate. The blood pressure reactions to infusions of epinephrine are represented in Table I by the averages of the deviations of five successive readings (taken during each five minute infusion at one minute intervals) from the respective pre-infusion levels (see also Figure 2).

The average elevation of the systolic blood pressure due to epinephrine increased with increasing doses from +6 to $+27 \mathrm{~mm}$. The diastolic pressure was depressed $8 \mathrm{~mm}$. average by 0.1 microgram per kilogram per minute of epinephrine but remained unchanged with 0.2 microgram per kilogram per minute and was increased $8 \mathrm{~mm}$. by 0.3 microgram per kilogram per minute.

Within the first five minutes after termination of the infusions, the systolic pressure returned 
TABLE I

\begin{tabular}{|c|c|c|c|c|c|c|c|c|c|c|c|}
\hline \multirow{2}{*}{$\begin{array}{c}\begin{array}{c}\text { No. } \\
\text { of } \\
\text { pt. }\end{array} \\
1\end{array}$} & \multirow{2}{*}{$\begin{array}{c}\text { Age } \\
56\end{array}$} & \multirow[b]{2}{*}{$\begin{array}{l}\text { Before DCA } \\
\text { After } 10 \text { days DCA }\end{array}$} & \multirow{2}{*}{$\begin{array}{c}\begin{array}{c}\text { Blood pr. } \\
\text { (resting } \\
\text { averages) }\end{array} \\
\\
\\
120 / 71 \\
139 / 85\end{array}$} & \multicolumn{3}{|c|}{$\begin{array}{l}\text { Bl. pr. response to infusion of } \\
\text { nor-epinephrine* }\end{array}$} & \multicolumn{3}{|c|}{$\begin{array}{l}\text { Bl. pr. response to infusion of } \\
\text { epinephrine* }\end{array}$} & \multicolumn{2}{|c|}{$\begin{array}{l}\text { Heart diameter } \\
(\mathrm{cm} .)\end{array}$} \\
\hline & & & & $\begin{array}{c}0.1 \gamma / \mathrm{kg} . / \\
\text { min. } \\
+16 /+16 \\
+14 /+5\end{array}$ & $\begin{array}{c}0.2 \gamma / \mathrm{kg} . / \\
\text { min. } \\
+30 /+20 \\
+33 /+18\end{array}$ & $\begin{array}{c}0.3 \gamma / \mathrm{kg} . / \\
\min . \\
-\end{array}$ & $\begin{array}{c}0.1 \gamma / \mathrm{kg} . / \\
\min . \\
-7 /-14 \\
+1 /-9\end{array}$ & $\begin{array}{c}0.2 \gamma / \mathrm{kg} . / \\
\min . \\
+20 / \pm 7 \\
+13 / \pm 2\end{array}$ & $\begin{array}{c}0.3 \gamma / \mathbf{k g} . / \\
\min . \\
=\end{array}$ & \begin{tabular}{|c|} 
Before DCA \\
12.6 \\
13.6
\end{tabular} & $\begin{array}{c}\text { Diff. afler } \\
\text { DCA } \\
\quad+1.0\end{array}$ \\
\hline 2 & 27 & $\begin{array}{l}\text { Before DCA } \\
\text { After } 13 \text { days DCA }\end{array}$ & $\begin{array}{l}166 / 109 \\
177 / 94\end{array}$ & $\begin{array}{l}+26 /+22 \\
+32 /+27\end{array}$ & $\overline{-}$ & 二 & $\begin{array}{l}+20 /-18 \\
+50 /-2\end{array}$ & $\overline{-}$ & 二 & $\begin{array}{l}16.0 \\
16.5\end{array}$ & +0.5 \\
\hline 3 & 16 & $\begin{array}{l}\text { Before DCA } \\
\text { After } 15 \text { days DCA }\end{array}$ & $\begin{array}{l}140 / 72 \\
143 / 84\end{array}$ & $\begin{array}{l}+6 /+7 \\
+13 /+17\end{array}$ & $\begin{array}{l}+16 /+16 \\
+21 /+26\end{array}$ & $\begin{array}{l}+20 /+17 \\
+46 /+35\end{array}$ & $\begin{array}{l}+10 /-2 \\
+24 /+10 \\
\end{array}$ & $\begin{array}{l}+17 / \pm 0 \\
+41 /+18\end{array}$ & $\begin{array}{l}+34 \%+8 \\
+60 \%+26 \\
\end{array}$ & $\begin{array}{l}10.7 \\
10.5\end{array}$ & -0.2 \\
\hline 4 & 43 & $\begin{array}{l}\text { Before DCA } \\
\text { After } 18 \text { days DCA }\end{array}$ & $\begin{array}{l}137 / 80 \\
140 / 88\end{array}$ & $\begin{array}{l} \pm 0 /+17 \\
+21 /+20\end{array}$ & $\begin{array}{l}+25 /+23 \\
+55 /+38\end{array}$ & $\begin{array}{l}+38 /+31 \\
+69 /+42\end{array}$ & $\begin{array}{l}+11 / \pm 0 \\
+8 /=4 \\
\end{array}$ & $\begin{array}{l}+30 /+7 \\
+33 /+4 \\
\end{array}$ & $\begin{array}{l}+37 /+13 \\
+60 /+14\end{array}$ & $\begin{array}{l}11.1 \\
11.9\end{array}$ & +0.8 \\
\hline 5 & 35 & $\begin{array}{l}\text { Before DCA } \\
\text { After } 18 \text { days DCA }\end{array}$ & $\begin{array}{l}136 / 93 \\
123 / 81 \\
\end{array}$ & $\begin{array}{l}+10 /+11 \\
+10 /+4 \\
\end{array}$ & $\begin{array}{l}+23 /+17 \\
+25 /+13 \\
\end{array}$ & $\begin{array}{l}+27 /+20 \\
+29 /+19 \\
\end{array}$ & $\begin{array}{r} \pm 0 /-9 \\
+3 /-7 \\
\end{array}$ & $\begin{array}{r}+8 /-1 \\
+22 /+8 \\
\end{array}$ & $\begin{array}{r}+16 /-5 \\
+26 /+11 \\
\end{array}$ & 三 & - \\
\hline 6 & 30 & $\begin{array}{l}\text { Before DCA } \\
\text { After } 18 \text { days DCA }\end{array}$ & $\begin{array}{l}156 / 85 \\
151 / 79\end{array}$ & $\begin{array}{l}+2 /+11 \\
+4 /+24\end{array}$ & $\begin{array}{l}+15 /+22 \\
+24 /+40\end{array}$ & $\begin{array}{l}+13 /+26 \\
+19 /+52\end{array}$ & $\begin{array}{l}+8 /-6 \\
+10 /+8 \\
\end{array}$ & $\begin{array}{r}+9 /-6 \\
+33 /+13 \\
\end{array}$ & 二 & $\begin{array}{l}13.1 \\
14.0\end{array}$ & +0.9 \\
\hline 7 & 46 & $\begin{array}{l}\text { Before DCA } \\
\text { After } 18 \text { days DCA }\end{array}$ & $\begin{array}{l}125 / 76 \\
108 / 74\end{array}$ & $\begin{array}{l} \pm 0 /+4 \\
+16 /+17\end{array}$ & $\begin{array}{l}+11 /+10 \\
+28 /+26\end{array}$ & $\begin{array}{l}+35 /+22 \\
+40 /+28 \\
\end{array}$ & $\begin{array}{r}+9 /-7 \\
+15 /+3 \\
\end{array}$ & $\begin{array}{r}+21 /-4 \\
+27 /+10 \\
\end{array}$ & $\begin{array}{r}+32 /+9 \\
+49 /+28 \\
\end{array}$ & $\begin{array}{ll}11.5 \\
11.6 \\
\end{array}$ & +0.1 \\
\hline 8 & 37 & $\begin{array}{l}\text { Before DCA } \\
\text { After } 22 \text { days DCA }\end{array}$ & $\begin{array}{l}156 / 87 \\
163 / 96\end{array}$ & $\begin{array}{l}+4 /+13 \\
+7 /+14 \\
\end{array}$ & $\begin{array}{l}+19 /+18 \\
+21 /+35\end{array}$ & $\overline{-}$ & $\begin{array}{l}+6 /=8 \\
+21 /=1\end{array}$ & $\begin{array}{l}+10 /+2 \\
+25 /+5\end{array}$ & $\begin{array}{l}+13 /+3 \\
+36 /+10\end{array}$ & $\begin{array}{l}13.4 \\
14.5\end{array}$ & +1.1 \\
\hline $9+$ & 39 & $\begin{array}{l}\text { Before DCA } \\
\text { After } 7 \text { days DCA }\end{array}$ & $\begin{array}{l}108 / 55 \\
134 / 79\end{array}$ & $\begin{array}{l} \pm 0 /+4 \\
+16 /+2\end{array}$ & $\begin{array}{l}+13 /+12 \\
+36 /+10\end{array}$ & $\begin{array}{l}+20 /+24 \\
+42 /+16\end{array}$ & $\begin{array}{l}+5 /-2 \\
+11 /=2\end{array}$ & $\begin{array}{l}+10 /+5 \\
+30 /+5\end{array}$ & $\begin{array}{l}+36 /+12 \\
+37 /+4\end{array}$ & 二 & - \\
\hline $10 \dagger$ & 54 & $\begin{array}{l}\text { Before DCA } \\
\text { After } 13 \text { days DCA }\end{array}$ & $\begin{array}{l}135 / 84 \\
127 / 79 \\
\end{array}$ & $\begin{array}{r}+9 /+7 \\
+12 /+8 \\
\end{array}$ & $\begin{array}{r}+28 /+18 \\
+27 /+18 \\
\end{array}$ & 二 & $\begin{array}{l}+8 /+1 \\
+5 /+2 \\
\end{array}$ & $\begin{array}{r}+22 /+9 \\
+17 /+4 \\
\end{array}$ & - & $\overline{-}$ & - \\
\hline $11 \dagger$ & 38 & $\begin{array}{l}\text { Before DCA } \\
\text { After } 18 \text { days DCA }\end{array}$ & $\begin{array}{l}128 / 77 \\
143 / 87\end{array}$ & $\begin{array}{r}+2 /+15 \\
+20 /+33\end{array}$ & $\begin{array}{l}+11 /+8 \\
+28 /+27\end{array}$ & $\begin{array}{l}+18 /+11 \\
+50 /+36 \\
\end{array}$ & $\begin{array}{l}\overline{1} 1 /-14 \\
+6 /+6\end{array}$ & $\begin{array}{l}+13 /-10 \\
+29 /+11 \\
\end{array}$ & $\begin{array}{l}+22 /+4 \\
+40 /+14\end{array}$ & $\begin{array}{l}13.7 \\
13.9\end{array}$ & +0.2 \\
\hline $12 \dagger$ & 22 & \begin{tabular}{|l|} 
Before DCA \\
After 19 days DCA
\end{tabular} & $\begin{array}{l}149 / 83 \\
145 / 103\end{array}$ & $\begin{array}{r}+5 /+51 \\
+48 /+31\end{array}$ & 三 & - & $\begin{array}{l}+11 /-10 \\
+15 / \pm 0\end{array}$ & $\begin{array}{l}+34 /-11 \\
+51 /+12\end{array}$ & $\overline{-}$ & $\begin{array}{l}13.6 \\
15.3\end{array}$ & +1.7 \\
\hline $13 t$ & 32 & \begin{tabular}{|l|} 
Before DCA \\
After 19 days DCA
\end{tabular} & $\begin{array}{l}144 / 92 \\
150 / 90\end{array}$ & $\begin{array}{l}+13 /+10 \\
+9 /+9 \\
\end{array}$ & $\begin{array}{l}+23 /+16 \\
+20 /+15 \\
\end{array}$ & $\begin{array}{l}+30 /+12 \\
+45 /+25 \\
\end{array}$ & $\begin{array}{r}+10 /-7 \\
+8 /+6 \\
\end{array}$ & $\begin{array}{r}+19 /-4 \\
+32 /+11 \\
\end{array}$ & 二 & $\begin{array}{l}11.5 \\
11.9\end{array}$ & +0.4 \\
\hline $14 \dagger$ & 37 & $\begin{array}{l}\text { Before DCA } \\
\text { After } 20 \text { days DCA }\end{array}$ & $\begin{array}{l}117 / 71 \\
118 / 74\end{array}$ & $\begin{array}{l}-2 /+9 \\
+6 /+9\end{array}$ & $\begin{array}{l}+29 /+29 \\
+38 /+30\end{array}$ & $\begin{array}{l}+48 /+34 \\
+66 /+44\end{array}$ & $\begin{array}{l}+2 /-6 \\
+10 /+3 \\
\end{array}$ & $\begin{array}{l}+6 /+1 \\
+29 /+12\end{array}$ & = & $\begin{array}{l}11.8 \\
12.6\end{array}$ & +0.8 \\
\hline $15 t$ & 37 & \begin{tabular}{|l|} 
Before DCA \\
After 20 days DCA
\end{tabular} & $\begin{array}{l}130 / 79 \\
132 / 88\end{array}$ & $\begin{array}{r}+7 /+13 \\
+25 /+15 \\
\end{array}$ & $\begin{array}{l}+24 /+16 \\
+32 /+26 \\
\end{array}$ & $=$ & $\begin{array}{r}-2 /-12 \\
+3 /-2 \\
\end{array}$ & $\begin{array}{r}+13 /+3 \\
+21 /+5 \\
\end{array}$ & = & $\begin{array}{l}11.2 \\
12.1 \\
\end{array}$ & +0.9 \\
\hline \multicolumn{2}{|c|}{ Av. of } & $\begin{array}{l}\text { Before DCA } \\
\text { After } 17 \text { days DCA }\end{array}$ & $\begin{array}{l}142 / 84 \\
143 / 85\end{array}$ & $\begin{array}{r}+8 /+13 \\
+15 /+16\end{array}$ & $\begin{array}{l}+20 /+18 \\
+30 /+28\end{array}$ & $\begin{array}{l}+27 /+23 \\
+41 /+35 \\
\end{array}$ & $\begin{array}{r}+7 /=8 \\
+17 / \pm 0 \\
\end{array}$ & $\begin{array}{l}+16 /+1 \\
+28 /+8 \\
\end{array}$ & $\begin{array}{l}+26 /+6 \\
+46 /+18 \\
\end{array}$ & $\begin{array}{l}12.6 \\
13.2\end{array}$ & +0.6 \\
\hline \multicolumn{2}{|c|}{$\begin{array}{l}\text { Av. of } \\
9-15 t\end{array}$} & $\begin{array}{l}\text { Before DCA } \\
\text { After } 17 \text { days DCA }\end{array}$ & $\begin{array}{l}130 / 77 \\
136 / 86\end{array}$ & $\begin{array}{l}+5 /+16 \\
+19 /+15\end{array}$ & $\begin{array}{l}+21 /+16 \\
+30 /+21\end{array}$ & $\begin{array}{l}+29 /+20 \\
+51 /+30\end{array}$ & $\begin{array}{l}+5 /-7 \\
+8 /+2\end{array}$ & $\begin{array}{l}+17 /-1 \\
+30 /+9\end{array}$ & $\begin{array}{l}+29 /+13 \\
+39 /+9\end{array}$ & $\begin{array}{l}12.4 \\
13.2\end{array}$ & +0.8 \\
\hline \multicolumn{2}{|c|}{$\begin{array}{l}\text { Total } \\
\text { average }\end{array}$} & \begin{tabular}{|l|} 
Before DCA \\
After 17 days DCA
\end{tabular} & $\begin{array}{l}136 / 81 \\
139 / 85 \\
\end{array}$ & $\begin{array}{r}+7 /+14 \\
+17 /+16 \\
\end{array}$ & $\begin{array}{l}+20 /+17 \\
+30 /+25 \\
\end{array}$ & $\begin{array}{l}+27 /+22 \\
+45 /+33 \\
\end{array}$ & $\begin{array}{r}+6 /-8 \\
+13 /+1 \\
\end{array}$ & $\begin{array}{r}+17 / \pm 0 \\
+29 /+8 \\
\end{array}$ & $\begin{array}{r}+27 /+8 \\
+44 /+15 \\
\end{array}$ & $\begin{array}{l}12.5 \\
13.2 \\
\end{array}$ & +0.7 \\
\hline \multicolumn{2}{|c|}{$\begin{array}{l}\text { Pulse pr. } \\
\text { average }\end{array}$} & $\begin{array}{l}\text { Before DCA } \\
\text { After } 17 \text { days DCA }\end{array}$ & $\begin{array}{l}55 \\
54\end{array}$ & $\begin{array}{l}40 \\
55\end{array}$ & $\begin{array}{l}57 \\
59\end{array}$ & $\begin{array}{l}60 \\
66\end{array}$ & $\begin{array}{l}69 \\
66\end{array}$ & $\begin{array}{l}72 \\
75\end{array}$ & $\begin{array}{l}74 \\
83\end{array}$ & & \\
\hline
\end{tabular}

* The figures under the captions "Blood pressure response to infusion of . . " indicate the average deviations of the systolic and diastolic pressures respectively of five consecutive readings (taken at one minute intervals during the five minute infusions) from the respective resting levels which were recorded immediately before beginning the infusions.

$\dagger$ The patients nos. 9-15 received 10 grams of extra salt daily to their normal diet during the periods of DCA injections

rapidly to normal or slightly below, while the diastolic pressure displayed a more marked tendency to drop temporarily below the original level (Table II).
After desoxycorticosterone acetate, with the average resting blood pressure level almost unchanged, the average depression of the diastolic pressure by 0.1 microgram per kilogram per min-

TABLE II

\begin{tabular}{|c|c|c|c|c|c|c|}
\hline & \multicolumn{3}{|c|}{ After infusion of nor-epinephrine } & \multicolumn{3}{|c|}{ After infusion of epinephrine } \\
\hline $\begin{array}{l}\text { Before DCA } \\
\text { After DCA }\end{array}$ & $\begin{array}{c}0.1 \gamma / \mathrm{kg} . / \mathrm{min} . \\
-4 / \pm 0 \\
\pm 0 /+1\end{array}$ & $\begin{array}{c}0.2 \gamma / \mathrm{kg} . / \min . \\
+1 / \pm 0 \\
+1 / \pm 0\end{array}$ & $\begin{array}{c}0.3 \gamma / \mathrm{kg} . / \mathrm{min} \\
-1 /-4 \\
-1 / \pm 0\end{array}$ & $\begin{array}{c}0.1 \gamma / \mathrm{kg} . / \mathrm{min} \\
+1 /-11 \\
-3 /-9\end{array}$ & $\begin{array}{c}0.2 \gamma / \mathrm{kg} . / \mathrm{min} . \\
+1 /-8 \\
-4 /-10\end{array}$ & $\begin{array}{c}0.3 \gamma / \mathrm{kg} . / \mathrm{min} . \\
-4 /-5 \\
-2 /-4\end{array}$ \\
\hline
\end{tabular}

Averages of the deviations of the lowest blood pressure levels reached within five minutes after the infusions from the respective pre-infusion levels. 
ute of epinephrine was transformed into a slight elevation and all systolic and diastolic pressor responses became intensified, again progressing with increasing dosage (for tests of significance, see Table II). There was practically no difference between the responses of groups $\mathrm{A}$ and $\mathrm{B}$. The average post-infusion behavior of the systolic and diastolic pressure after treatment with desoxycorticosterone acetate was not significantly altered.

(5) Pressor effect of l-nor-epinephrine before and after desoxycorticosterone acetate. The effects of nor-epinephrine infusions on the systolic blood pressure were almost identical with those of equal doses of epinephrine (Table I, Figures 1 and 2), whereas the diastolic pressure became elevated without exception and in a much greater degree than by epinephrine.

The post-infusion reaction within the first five minutes consisted essentially of a return to normal and there was no depression of the average diastolic pressure comparable to that produced by epinephrine (Table II, Figure 1).

After desoxycorticosterone acetate the systolic pressor effect of nor-epinephrine was intensified in about the same manner as the systolic pressor effect of epinephrine. The diastolic pressor effect was also augmented in a similar degree as the diastolic pressor effect of epinephrine but on a higher level, in keeping with the greater elevation of the diastolic pressure, caused by nor-epinephrine per se (for tests of significance see Table II).
There were no appreciable differences in the reactions of groups $\mathrm{A}$ and $\mathrm{B}$.

The post-infusion reactions after desoxycorticosterone pre-treatment did not significantly differ from those elicited before administration of desoxycorticosterone acetate.

The electrocardiographic results will be presented separately.

\section{COMMENT}

(A) Effects of epinephrine and nor-epinephrine per se. Various features, noticed during the intravenous infusion of epinephrine and norepinephrine, were in agreement with observations made previously by other investigators with similar techniques; for instance, the depression of the diastolic blood pressure by infusion of small doses of epinephrine $(21,22)$; the generally greater systolic pressor effect of epinephrine, compared with its diastolic effect (22); by contrast, the approximately equal systolic and diastolic pressor action and the bradycardia-producing effect of nor-epinephrine (18-20); the almost complete absence of subjective sensations during the infusion of nor-epinephrine, regardless of the degree of blood pressure elevation $(18,19)$.

(B) Effects of desoxycorticosterone acetate per se. Larger doses and a more prolonged medication had been purposely avoided in order not to create significantly different basal blood pressure levels for the epinephrine and nor-epinephrine

TABLE III

Increase of pressor response to epinephrine and nor-epinephrine after desoxycorticosterone acetate*

\begin{tabular}{|c|c|c|c|}
\hline Dose & $0.1 \gamma / \mathrm{kg} . / \mathrm{min}$. & $0.2 \gamma / \mathrm{kg} . / \mathrm{min}$ & $0.3 \gamma / \mathrm{kg} . / \mathrm{min}$. \\
\hline \multicolumn{4}{|c|}{ Epinephrine } \\
\hline $\begin{array}{l}\text { Systolic }(\mathrm{mm} . \mathrm{Hg}) \\
\text { Diastolic }(\mathrm{mm} . \mathrm{Hg})\end{array}$ & $\begin{array}{l}6.67 \pm 2.16(15) \\
7.67 \pm 2.02(15)\end{array}$ & $\begin{array}{r}13.43 \pm 3.17(14) \\
8.43 \pm 2.31(14)\end{array}$ & $\begin{array}{r}16.86 \pm 3.30(7) \\
9.00 \pm 3.55(7)\end{array}$ \\
\hline
\end{tabular}

Nor-epinephrine

\begin{tabular}{|c|c|c|c|}
\hline $\begin{array}{l}\text { Systolic }(m m . H g) \\
\text { Diastolic }(m m . H g)\end{array}$ & $\begin{array}{r}10.33 \pm 3.12(15) \\
1.67 \pm 2.52(15)\end{array}$ & $\begin{array}{l}9.31 \pm 2.71(13) \\
7.46 \pm 2.48(13)\end{array}$ & $\begin{array}{l}17.44 \pm 3.77(9) \\
11.11 \pm 3.41(9)\end{array}$ \\
\hline
\end{tabular}


tests before and after treatment with desoxycorticosterone acetate.

The enlargements of the hearts of normotensive subjects, as seen in this series (in groups $A$ and $B$ alike) under the influence of desoxycorticosterone acetate, were only of a small degree but may not have been entirely insignificant in view of their uniformity and of the existence of similar, more striking observations, recorded in the literature $(7,23)$.

(C) Effects of epinephrine and nor-epinephrine after pretreatment with desoxycorticosterone acetate. The intensified pressor effect of intravenously infused epinephrine in desoxycorticosterone acetate-pretreated patients proves that similar results, obtained previously by use of the subcutaneous route $(7,8)$, cannot be attributed to differences of epinephrine absorption from the subcutaneous tissue.

It also seems most unlikely that the intensification of the pressor effects of the sympathomimetic amines should have been caused by a retention of water and increase of the circulatory volume. Neither in group A nor in group B was there a significant increase in average body weight and earlier observations by others $(24,25)$ militate against a major significance of water retention in the mechanism of desoxycorticosterone-induced cardiovascular alterations.

The fact that desoxycorticosterone acetate intensified the pressor effect of nor-epinephrine as well seems of particular interest concerning the problem of essential hypertension in view of the possible pathogenic role of the sympathetic neurosecretion of nor-epinephrine into the vascular contractile effector cells and of an enhancement of its local constrictive efficiency under adrenal cortical influence (26). It is true that desoxycorticosterone proper seems to be present in the adrenal cortex in only small amounts (27) but on the grounds of extensive experimental and clinical observations it is generally regarded as an acceptable function representative of the naturally occurring "mineralo-corticoids."

According to a recent report, the pressor effect of epinephrine in rats was only slightly and irregularly increased after pretreatment with desoxycorticosterone acetate (28). This is to be explained in all likelihood by that fact that these animals had been made hypertensive by desoxy- corticosterone acetate in contrast to our human subjects whose blood pressure remained practically unchanged and that consequently the basis for comparison was a different one. The frequent absence of an increased pressor effect of epinephrine also in hypertensive humans has been repeatedly observed $(18,21,22,29)$.

As a working hypothesis, the desoxycorticosterone-induced hypertension itself may be regarded as the result of a potentiation of the pressor efficiency of the intrinsic neurogenic norepinephrine deposits within the vascular muscle cells through desoxycorticosterone action. Studies concerning this point and the part played by the sodium ion in the mechanism of vascular pressor responsiveness are in progress.

While several investigators have reported a distinct accentuation of the blood pressure-elevating effect of desoxycorticosterone through the simultaneous intake of excessive amounts of sodium chloride $(8,30-33)$, the quantity and duration of extra salt intake in our cases of group B was obviously not sufficient to produce this phenomenon in a significant measure.

\section{SUM MARY}

Graded intravenous infusions of 1-nor-epinephrine and of epinephrine ( 0.1 to 0.3 microgram per kilogram per minute) in 12 non-hypertensive and three borderline hypertensive males produced pressor effects of specifically different patterns.

Administration of desoxycorticosterone acetate (10 mg. daily over an average of 17 days) did not alter the average resting blood pressure level of eight subjects who were on a normal diet. That of seven others who received in addition 10 grams of sodium chloride per day during the desoxycorticosterone acetate medication, became slightly elevated.

The average pressor effects of both 1-norepinephrine and epinephrine (systolic and diastolic) were significantly intensified after desoxycorticosterone acetate, except for the diastolic response to the smallest dose of 1-nor-epinephrine. Addition of extra salt to the diet did not appreciably influence these reactions.

The average level of serum sodium was unchanged at the end of desoxycorticosterone administration; the potassium level was diminished. The heart diameters became slightly enlarged. 
The possibility was briefly discussed that a potentiation of sympathomimetic pressor effects (due to intrinsic neurogenic nor-epinephrine in the vascular contractile cells and to circulating epinephrine and nor-epinephrine) under the influence of an exaggerated adrenocortical activity may be a pathogenic factor in essential hypertension.

\section{ACKNOWLEDGMENT}

We are indebted to Dr. Wm. v. B. Robertson for the electrolyte determinations and for calculation of the Fisher $t$-values for significance, and to Miss Wilda Gigee, R.N., A.B., for technical assistance.

\section{BIBLIOGRAPHY}

1. Shorr, E., Participation of hepatorenal vasotropic factors in experimental renal hypertension. Am. J. Med., 1948, 4, 120.

2a. Mylon, E., Horton, F. H., and Levy, R. P., Influence of epinephrine on vasoconstrictive action of organ extracts. Proc. Soc. Exper. Biol. \& Med., 1947, 66, 378.

b. Mylon, E., and Heller, J. H., Activation of hypertension and tyrosine by subthreshold amounts of epinephrine. Ibid., 1948, 67, 62.

3. Zweifach, B. W., Shorr, E., Baez, S., and Rosenfeld, S., Hepato-renal factors in circulatory homeostasis; relation of adrenals to formation of a renal vasoexcitor principle. J. Clin. Endocrinol., 1947, 7, 460.

4. Payne, M. A., and Shorr, E., Hepato-renal factors in circulatory homeostasis. XXV. Low protein diets and renal VEM formation. Federation Proc., 1949, 8, 125.

5. Sanders, E., Ueber die Wirkung von reinem Adrenalin und Nebennierenextrakten per os und am isolierten Organ. Arch. f. exper. Path. u. Pharmakol., 1938, 188, 657.

6. Osterwald, K. H., Zur Kreislaufwirkung des Nebennierenrindenhormons. Arch. f. Kreislaufforsch., 1948, 14, 205.

7. Raab, W., Cardiovascular effects of desoxycorticosterone acetate in man. Am. Heart J., 1942, 24, 365.

8. Sarre, $H$., Untersuchungen über Beziehungen zwischen Hochdruck. Nebennierenrindenhormon und Kochsalz. Deutsches Arch f. klin. Med., 1944, 192, 167.

9. Rosenow, G., and Jaguttis, Blood sugar in Addison's disease. Klin. Wchnschr., 1922, 1, 358.

10. Thaddea, S., Die Nebennierenrinde: Beiträge zur experimentellen und klinischen Pathologie. Georg Thieme, Leipzig, 1936.

11. am Ende, S., Ueber die dissoziierte und allgemeine Störung der Adrenalinreaktivität bei Nebennierenrindeninsuffizienz. Ztschr. f. klin. Med., 1939, 136, 108.
12. Schürger, G., Ueber den Einfluss des Nebennierenrindenhormons auf die Ermüdbarkeit und den Muskelstoff wechsel des Herzens. Klin. Wchnschr., 1947, 24-25, 593.

13. Raab, W., and Lepeschkin, E., Unpublished data.

14. Holtz, P., Sympathin-Chemische Uebertragung sympathischer Nervenerregungen. Klin. Wchnschr., 1950, 28, 145.

15. Goldenberg, M., Faber, M., Alston, E. J., and Chargaff, E. C., Evidence for the occurrence of norepinephrine in the adrenal medulla. Science, 1949, 109, 534.

16. Bülbring, E., and Burn, J. H., Liberation of noradrenaline from the suprarenal gland. Brit. J. Pharmacol., 1949, 4, 202.

17. v. Euler, U. S., A specific sympathomimetic ergone in adrenergic nerve fibres (sympathin) and its relation to adrenaline and nor-adrenaline. Acta physiol. Scandinav., 1946, 12, 73.

18. Goldenberg, M., Pines, K. L., Baldwin, E. de F., Greene, D. G., and Roh, C. E., The hemodynamic response of man to nor-epinephrine and epinephrine and its relation to the problem of hypertension. Am. J. Med., 1948, 5, 792.

19. Barcroft, $H$., and Konzett, $H$. ., Action of noradrenaline and adrenaline on human heart rate. Lancet, 1949, $1,147$.

20. Swan, H. J. C., Effect of noradrenaline on the human circulation. Lancet, 1949, 2, 508.

21. Green, D. M., Johnson, A. D., Lobb, A., and Cusick, G., The effects of adrenaline in normal and hypertensive patients in relation to the mechanism of sustained pressure elevations. J. Lab. \& Clin. Med., 1948, 33, 332.

22. Fatherree, T. J., and Hines, E. A., Jr., The blood pressure response to epinephrine, administered intravenously to subjects with normal blood pressure and to patients with essential hypertension. Am. Heart J., 1938, 16, 66.

23. Perera, G. A., Knowlton, A. I., Lowell, A., and Loeb, R. F., Effect of desoxycorticosterone acetate on the blood pressure of man. J.A.M.A., 1944, 125, 1030.

24. Perera, G. A., and Blood, D. W., Pressor activity of desoxycorticosterone acetate in normotensive and hypertensive subjects. Ann. Int. Med., 1947, 27, 401.

25. Altschule, M. D., and Zamcheck, N., Studies on the circulation and respiration in a patient with anasarca following administration of cortin and sodium chloride. J. Clin. Endocrinol., 1942, 2, 269.

26. Raab, W., The pathogenic patterns of essential hypertension. Exper. Med. \& Surg., 1948, 6, 464.

27. Reichstein, T., Chemie des Cortins und seiner Begleitstoffe. Ergebn. d. Vitamin -u. Hormonforsch., 1938, 1, 334.

28. Masson, G. M. C., Page, I. H., and Corcoran, A. C., 
Vascular reactivity of rats and dogs treated with desoxycorticosterone acetate. Proc. Soc. Exper. Biol. \& Med., 1950, 73, 434.

29. Koehler, A. E., Marsh, N., and Hill, E., The effect of epinephrine injected intravenously at a constant rate in normal and hypertensive cases. J. Biol. Chem., 1937, 119, lix.

30. Friedman, S. M., Friedman, C. L., and Polley, J. R., Potentiation of the hypertensive effects of desoxycorticosterone acetate (DCA) by various sodium salts. Am. J. Physiol., 1948, 153, 226.

31. Knowlton, A. I., Loeb, E. N., Stoerk, H. C., and
Seegal, B. C., Desoxycorticosterone acetate; the potentiation of its activity by sodium chloride. J. Exper. Med., 1947, 85, 187.

32. Green, D. M., Coleman, D. H., and McCabe, M., Mechanisms of desoxycorticosterone action; relation of sodium chloride intake to fluid exchange, pressor effects and survival. Am. J. Physiol., 1948, 154, 465.

33. Gross, F., Die Wirkung von Desoxycorticosteronacetat und Kochsalz auf den experimentellen Hochdruck der Ratte. Arch. internat. de pharmacodyn. et de thérap., 1950, 81, 211. 